\section{História de quatro "M"}

Tradução de Juremir Machado da Silva
RégisDebray
E SE QUALQUER SISTEMA fosse uma obra de arte fracassada? E se o próprio fato de exprimir-se em geral, sem sujeito singular, dirigindo-se a todos, urbi et orbi, sem destinatário específico, nem lugar ou data, fosse a renúncia dissimulada à obra que poderia ter sido ou nascido se a teoria tivesse, conforme o consel ho proustiano, conservado a "força de restringir-se a acompanhar uma impressão através dos seus estados sucessivos até se fixar na expressão"? Nesse caso, o aprendiz de teórico deveria, senão desistir dos gráficos, glossários, correlações e leis, ao menos seguir "o rastro que o mundo imprime em nós, o único real, autêntico".

Então o impessoal peremptório e teatral das operações cognitivas se apagaria, com honestidade e modéstia, diante do eu narrativo, acidental, incoerente, talvez, de uma seqüência singular de impressões, uma entre outras. Cada membro da orquestra poderia dizer ao colega ao terminar o seu fragmento: Tell your story. Conta a tua história. Entra no coro. Modula o tema do teu jeito. É a tua vez de jogar e de dizer como chegaste aonde estás, passando por onde.

Para o signatário, o tema midiológico (que cada integrante da orquestra dos Cahiers de $M$ édiologie, como bom jazzman, rearranja à sua maneira) atravessou quatro estados sucessivos, quatro etapas ascensionais: mensagem, médium, meio, mediação. " $M$ " de mensagem como militância, messianismo; ministério. " $M$ " de médium como memória, material, maquinaria, monumento. " $M$ " de meio como mundo, modo, macrossistema técnico, média (onda), in medio stat virtus. " $M$ " de mediação como mistura, maldição ou milagre. História de conceitos, história de uma vida, cada um tem o seu labirinto de entrada.

A bra-se o mídio de midiologia e, venhase de onde vier, descobre-se uma boneca russa: de fora para dentro, os mídia, o mé 
dium, o mediano, o mediato. Muda-se uma letra, desloca-se a ênfase, numa relação em cadeia. A midiologia representa o fim de um trabalho progressivo de desmontagem; o final ideal, interminável, de uma labuta bastante lenta e meticulosa de decantação, desencaixe, desatolo - ciclo sem fim, cujas espirais sempre recomeçam.

Quatro paradas para esclarecimento. Vale dizer quatro exílios, quatro lutos, quatro motivos de exclusão (fora dos muros do saber legítimo), quatro torções-expatriações. Longe de ser uma fuga para frente, é como que um zoom para trás, graças ao qual se iria, a cada pausa, para aumentar a inteligibilidade, do condicionado à sua condição de existência. Assim, a ordem de exposição inverte aqui a ordem dos fatores. Passaremos da práxis (1) à tecné (2), à eco (3) e, enfim, à antropo (4). Mas é a antropologia extensa que estabelece de direito a ecologia cultural; esta determina uma tecnologia simbólica da qual deriva uma pragmática das mensagens. No lugar do "quem diz o que a quem e por qual canal?", encontra-se em síntese um "que fazer, como, por onde e sob quais restrições?"

Cada parada supõe uma mudança de escalas cronológica e espacial: a mensagem individual pertence ao momento, hic et nunc; o médium utilizado corresponde a uma época; o meio, continental, é uma sedimentação secular; e a mediação é multimilenar, própria à espécie, trans-histórica.

Fase I- a mensagem. E não o enunciado; a idéia relacionada com os seus efeitos. $\mathrm{N}$ ão os belos efeitos do sentido para futuros exegetas (no jogo interminável das hermenêuticas), mas os da emoção popular, de armamento, de choque. Idéias que levam a tomar a Bastilha, decidir, arriscar, cair na clandestinidade. Prometi falar a verdade? Meu começo foi político. Limitado e superficialmente político. Quem diz político, diz emoção, multidão, grupo, movimento de opinião, hierarquia, comando, algo diferente de uma calma troca de informações entre dois interlocutores, de um “ato de comunicação" em tête-à-tête, do par emissor/ receptor, pura robinsonada. Raiva de falar para não fazer nada. Desgosto diante da conversa fiada intelectualóide, dos jargões universitários, do jogo vitalício da interpretação, do comentário de texto. Crer nas idéias, nos debates de idéias? Puxa! Assim como uma época se define pelo que aceita como real, a juventude define-se pelo que considera como de fato sério.

Ao sair da escola, não levava a sério a história das idéias, mas a história simplesmente; a primeira só interessava como meio para agir sobre e na segunda. Propaganda, tática, administração, influência, rede, hegemonia, difusão; esses obstáculos, posteriores ao sábio ou ao poeta, estão na origem do trabalho do militante ou do evangelizador (homem de mensagens e de boas novas). Lênin em vez de Marx; Gramsci em vez de Althusser. Ambos jornalistas. Não "que se deve pensar?", mas "que fazer para fazer os outros pensarem?" - o fazer pensar tendo, no caso, um único objetivo: fazer fazer (eu penso, logo tu me segues). R evol ução na revolução? A longa marcha do castrismo, etc... Textos deliberadamente de circunstância, de publicista, de agitador - nos quais dizer a verdade (suponhamos) deve significar pôr fogo na planície, o que servirá de parâmetro de julgamento.

Definição do “intelectual revolucionário" (espécie que nasceu e morreu neste século): aquele cuja vida se organiza em torno de uma idéia e que, através de uma vanguarda organizada, pretende organizar a vida dos outros de acordo com a sua ideologia, conforme o postulado que adota, como bom herdeiro, jacobino e francês, segundo o qual Voltaire e Rousseau autorizam Siéyès e Saint-Just; o Iluminismo, 1789; o pensamento, a rebelião. Signos e massas. Chamemos assim aquele que escreve livros, ou principalmente artigos, brochuras, panfletos ao alcance de todos (mais assimiláveis e anabolizantes do que o pesado e o sofisticado) para que tipos gráficos se metabolizem em movimentos de massa, 
transformações de uma situação, operações deforça.

Ao contrário do pensador, negativo e contemplativo, o intelectual é um organizador positivo, cujo mandato consiste em estabelecer a conexão, a ponte, a mediação entre a idéia e as pessoas. Trata-se, nesse sentido, de alguém que encarna algo; corporifica, encena, aciona um esquema abstrato. Quando um etnólogo ou um psicanalista falam de "eficácia simbólica", o primeiro termo vem, com freqüência, atrelado ao segundo, numa feliz concessão, comércio social de uma dignidade primordial, o simbólico; para o aprendiz de midiólogo, a ênfase recai, ao contrário, sobre eficácia, substantivo que admite, numa modalidade entre outras, a emissão de signos. Dessa primazia dada à ação, resultará um ângulo de ataque, uma maneira incontornável de ver as coisas, marca sobrevivente às ilusões (ou à valentia, à juventude, à ingenuidade) do engajamento partidário - o pacífico Valéry já se surpreendia com "o que se deve ignorar para agir".

Não mais, o que isso quer dizer em si mesmo?, mas como isso funciona? Para que serve isso? O que isso mobiliza? - a representação visual (H istória do ol har no 0 cidente), a instituição estatal (0 Estado sedutor), a função intelectual (Le Scribe). O midiólogo sempre pertencerá, de coração e razão, ao partido pragmático (que não se limita à escola de mesmo nome, mesmo se a midiologia, como afirma Daniel Bougnoux, pode, utilmente, se atrelar a ela).

O espírito do tempo (França, 1960/ 1970) considera secundários ou acessórios os terrenos vagos da doxa - a opinião situados abaixo dos caminhos íngremes da ciência, escalados em força pelos primeiros da caravana de alpinistas filosóficos. H egemonia, palavra-chave, na qual o suposto resultado encobre a consideração concreta dos meios e dos métodos. Os novos marxistas esforçam-se para deslocar o peso ide ologia (o jogo das idéias no silêncio dos suportes) na direção do campo prático, atrelando-a a aparelhos, vagas e ameaçadoras imaterialidades, fantasiando-a com uma "eficácia relativa"; a noção continua, porém, recoberta pela ótica marxista, quintessência da inanidade, como engodo, imagem invertida das coisas, fantasmagoria inconsistente reflexo na camara oscura das consciências.

O avô Marx emagrece, mas o que é capaz de inflar nos anos Lacan, Barthes, Baudrillard - com Saussure abrindo caminho? A sêmio, o código, o significante. $O$ mundo-linguagem. N ova Crítica. Tel Quel. Comunicação. Metáfora e metonímia. Retórica e semântica. Aí reside o sério, o núcleo do sentido. $O$ enfado da contabilidade permanece na periferia, entregue aos hilotas da história das técnicas ou das mentalidades, ou então a uma vaga psicologia das massas, entre Le Bon e o Jung que fala de hipnose, contágio, influência, impressionabilidade - mas não de acústica, concha, microfone, ondas, cordas vocais. Vulgarização, difusão, rede, genealogia dos efeitos de autoridade: não se fala de logística na Casa do Pai.

Os filósofos marxistas não têm o me nor interesse pela maneira através da qual a mão de Marx (correndo tinta no papel) conseguiu produzir no outro extremo, na rua, cabeças marxistas e mãos com bandeiras vermelhas. "A teoria é Todo-poderosa porque é verdadeira." Descoberta lenta, perturbadora, incômoda: os teólogos cristãos são mil vezes mais avançados do que os "materialistas científicos" na identificação do fenômeno dito performativo da transferência de potência. Ao menos aí, "o Verbo se fez carne" é desdobrado como um núcleo, infinitamente problemático e nevrálgico, um verdadeiro mistério da fé. Péguy adiantado em relação a Althusser? Vertigens....

Esses anos de chumbo (1961-1973, desprovidos por meu lado de qualquer tentativa teórica ou categórica) imprimiram ao que se seguiu a mácula indestrutível do trivial. O midiólogo falará banalmente de coisas banais. Diante do chique da semiótica in, dos refinamentos e firulas de artis- 
tas, Paris-Roma-Nova York, o seu lado grosseiro o remeterá de preferência a Romorantin. Será preciso aceitar a realidade, a vocação do off. Azar.

Fase ll-o médium. A pragmática pare ce maneta, contornando demasiadamente as pressões materiais. Tributária de uma abstração cartesiana, dramatiza o cogito como práxis, o idealismo como ativismo, sem realmente romper com o sujeito solitário e soberano. A ação direta, belo sonho do homem-Deus... O sujeito agindo sobre as representações de outro sujeito através de signos... como se esses signos demasiadamente famosos existissem por si mesmos, caídos do céu, sem suporte de inscrição, sem vetor, sem memorização. Eis o que quebra certos encantamentos existenciais, fenomenológicos, psicanalíticos - mas como ignorar o instrumental?

Para compreender os negócios humanos (os pragmatas), é necessário exilar-se fora do império dos signos para abordar o pobre reino do objeto, das "máquinas inumanas", admitindo-se que a relação semiótica sujeito/ sujeito é sempre mediatizada pelo material e pelo físico (não há fala, no sentido mais simples, sem ondas sonoras, cordas vocais et laringe...) A análise da mensagem não basta a si mesma. (Um mesmo signo, da espécie índice, ícone ou símbolo, não tem os mesmos efeitos, culturais e práticos, na medida em que é disseminado em cadeia (manuscrito) em estrela (impresso) ou em rede (digital). Uma imagem animada não é a mesma se gerada (televisão) ou projetada (cinema). O poema iluminado em pergaminho ou jogado na Net....

A chave da semiosfera está na tecnosfera? Fim dos confortáveis textos a texto. É preciso sair das palavras, molhar a camiseta, abrir, oh, vergonha!, manuais de aprendiz, passar da Sorbonne aos A rts et M étiers [Artes e Ofícios]. Decair. Mas em qual materialidade seria preciso se iniciar? Para qual categoria de objetos ou de aparelhos se voltar? Nesse ponto, um mil utilidades, vale para tudo, apresenta-se: os "mídia". A palavra impõe-se sozinha; a coisa, visível a olho nu, também: imprensa escrita, falada e audiovisual. Os mass-mídia. Já vem pronto; é pegar ou largar. Prega-se moral em cima disso, contra ou a favor. Sociologiza-se. Profetiza-se.

$E$ eis que o midiólogo é repentinamente ligado ao imenso rumor, a um oráculo célebre e mal-afamado (no mundo universitário), McLuhan, provocador genial, a "ciências" em via de constituição, por decreto ministerial (criação da 7ạ Seção do C.N.U.): o "Infocom". Vinte anos depois, e embora nenhum número dos Cahiers tenha escolhido por tema o rádio, a televisão ou a grande imprensa, basta que alguém revele num jantar a sua qualidade de "midiólogo" para que se encadeiem comentários do tipo: "Ah, então Poivre d'Arvor [apresentador do telejornal de maior audiência na França] é bom ou ruim?"

Eis a vantagem de ser arcaico, apegado a velharias: as religiões, Jesus de Nazaré, Auguste Comte de Paris, os socialismos, Marx, o renano, Proudhon, o jurassiano. Leitor de livros de história antiga. Reflexão: a mídia, certo, é deslumbrante, mas, enfim, existia vida antes de Marconi, de Hertz e de Edison. O cristianismo não se disseminou em broadcast, nem o marxismo por telégrafo. Há outra coisa ou, antes, a mesma sob outras formas. O princípio de continuidade exige distanciamento, ou seja: ex nihilo nihil fit. Aquilo que é ativo hoje, devia sêlo ontem. Nossos ancestrais não possuíam as mesmas panóplias, mas tinham as mesmas competências que nós.

As leis da história, do grupo, da troca, não mudaram de um dia para outro, com o aparecimento da eletricidade e do elétron. Nem mesmo antes, com os tipos móveis e o papel chifon. Disso resulta a suspeita de que a mídia, palavra total, não contém o seu próprio princípio de inteligibilidade. Que esse campo de estudos e de realidade peca por excesso de espessura (especialmente temporal). Que a nossa mídia é, no fundo, uma variação contemporânea, hi- 
pertrofiada, ensurdecedora, superexposta, de uma invariante básica mais encoberto, menos provocante e, contudo, presente em todos os modos de comunicação, em todos os estádios cronológicos da circulação dos signos: o dispositivo da veiculação. Órgão da transmissão. O suporte invisível, em grego upokeimenon, que se encontra abaixo, sem se mostrar. Chamemo-lo de médium, termo neutro e singular (facecioso presente do espiritismo, na língua francesa, ao materialismo ou do divinatório ao operatório).

Se esse excesso é reduzido à essência, sua perspectiva poderia ser comparada à alta Antigüidade assim como à petulante pós-modernidade. Isso consistiria no seu exame de passagem epistemológico.

A tenção: o médium nunca vem pronto. Deve ser elaborado através de operações delimitadas de conhecimento. Nada tem a ver com o que se chama de "mídia". O museu, por exemplo, serviu e ainda serve de médium à "obra de arte". " $A$ " serve de médium a " $B$ " quando " $B$ " se concretiza graças a " $A$ ", não sendo possível, praticamente, sem " $A$ ". A situação "médium" de um objeto " $x$ ", o qual não é o por si mesmo nem em todas as suas relações, é precisamente o resultado de certo trabal ho de análise, o produto de um procedimento "midiológico". A midiologia é uma atividade lógica de cruzamento de elementos sem relação aparente que produz essa abstração argumentada, paradoxal e ignorada chamada médium.

Parece-me que a abordagem resumida aqui se distingue claramente da "infocom" tradicional (para não dizer que ela é de natureza completamente diferente) ao mesmo tempo pela extensão, mais ampla, e pela definição, mais discriminatória, dada à nossa esfera comum de interesses. Sabe-se com que laxismo o cavaleiro autor do médium is message, e seus adeptos póstumos, tendem a confundir, num mesmo termo, um procedimento geral de simbolização (parole, écriture, imagem analógica, forma digital); um código social de comunicação (a língua, latim, inglês ou tcheco); um suporte material de ins- crição e de estocagem (argila, papiro, pergaminho, papel, fita magnética, tela) e um dispositivo de registro e de difusão (manuscrito, impresso, foto, televisão, informática).

Não saber de que se fala é uma grande vantagem da qual não se deve abusar. Nessa palavra, é preciso combinar duas restrições. O médium não é menos corporeidade do que materialidade. Há instrumento, e há gesto, pessoal ou coletivo; há o conjunto M.O (matéria organizada) e o O.M (organização materializada). A escrita alfabética, por exemplo, é um procedimento (técnico) cuja transmissão social supõe ao mesmo tempo, de um lado, papel, instrumentos de inscrição, livros (transmissores inertes) e, por outro lado, escola, editoras, um corpo docente (transmissores animados). Os suportes técnicos de informação aparecem então inscritos em e através de relações organizacionais com funções estratégicas, "privados" ou "públicos" (Agências, Centros, Empresas, Caixas, Comissões, Institutos, etc...).

A escrita, a ortografia e as reformas desta, na França como na Alemanha, foram e continuam a ser questão de Estado (mobilizando a Corte Constitucional, Ministérios, Academias e Tribunais). Sempre como lição das coisas, pode-se dizer que para fazer circular um cavaleiro no império romano, precisava-se de:

1-uma estrada pavimentada (via Appia, Domitia, etc...).

2-um cavalo.

3-uma rede global de expedição (postos de troca, armazéns, guarnições, aprovisionamento).

4-a língua latina (para codificar e decodificar a informação emitida ou recebida pelo mensageiro.

5-um Estado central coletor de impostos e distribuidor de ordens (Senatus populusque romanus).

6-um sistema de representações coletivas (moral, disciplina, vontade de poder).

Retire-se qualquer um desses elementos, por hipótese, e o cavaleiro fica parali- 
sado. Seja fisicamente (1-2-3), seja mentalmente (4-5-6).

Aquilo que N ietzsche dizia dos filósofos vale também para os especialistas da "Com": "Pecam originalmente por falta de sentido histórico".

Acrescentemos em corolário - estrategicamente. Por essa hipótese, os mídia são armas e não canais ou próteses (ver as reflexões de F.B. Huyghe).

Tudo leva a crer, talvez sem razão, que na galáxia Infocom, estima-se por vezes que o material de guerra (M.O.) basta para guerrear, sem necessidade de pessoal, ou seja, sem: 1 - batalhões, armados, comandados e hierarquizados; $2-$ um governo central acima, fixando os objetivos da guerra; e 3 - as escolas de guerra, formando tática e estrategicamente o pessoal, assim como preparando-o para manejar o material (O.M.).

Tal seria o efeito das divisões disciplinares vigentes e, particularmente, da compartimentação universitária das ciências políticas/infocom: não perceber que os atos e os aparelhos da comunicação fazem parte dos limites comunitários, esquecendo que as operações simbólicas, baseadas na técnica, funcionam sobre um fundo "político". (O jornal do Partido extrai a sua força do Partido, mesmo que este não pudesse existir sem aquele. A pregação do pregador extrai a sua eficácia da igreja à qual pertence, etc...) Os signos não possuem o próprio motor incorporado. As pesquisas empíricas "à americana" preenchem a metade do programa, o dispositivo semiótico sem o agenciamento imóvel e motor (a força das instituições, e a fortiori das religiões, associada à essa imobilidade).

Ora, as telecom do tempo - a política é arte de durar, o tempo de impor os seus códigos - negociam sem parar com as telecom do espaço (com freqüência modelizadas a partir do esqueleto telefônico e sincrônico "emissor - mensagem - receptor", quando se trata de construir estrategicamente essa sincronia, objeto de uma relação de forças entre comunicantes). Obser-

ve-se que a amputação de um médium de dupla trama, com todas as articulações abolidas, pode também se operar em sentido contrário, em detrimento da maquinaria e de suas pressões internas, em benefício do agenciamento político externo. É a tendência das sociologias "à européia", simbolizadas pela Escola de Frankfurt. ${ }^{1}$

Médium... = conjuntos das disposições de veiculação

Dispositivos técnicos

Dispositivos orgânicos

1.Superfície de inscrição

(rolo, tabletes, codex...)

1.Vetor lingüístico (aramaico, latim, inglês)

2.Registro simbólico

2.Instituição intermediária

(escrita, imagem, som...)

(igrejas, Estados, escolas, partidos, etc)

3.Aparelho reprodução/difusão

(um-um, um-todos, todos-todos)

3.Rituais, códigos e matrizes (veiculados)

$=$ M.O. (matéria organizada)

=0.M. (organização materializada)

Poder-se-ia ampliar esse esquema para a esfera da circulação dos signos e dos homens na sua totalidade. Ter-se-ia, em grande escala, a seguinte superposição:

Midio(logia) $=$ componentes de um sistema circulatório

Meios de circulação

1.Suporte ou médium passivo

(estrada, tela, papel, etc...)

2.Veículo propriamente dito ou médium ativo

(bicicleta ou carro, alfabeto ou ideograma, ou ideograma, imagem pintada ou foto, etc)

3.Rede ou médium distributivo

(rodoviário, impresso, hertziano, digitala, etc)

$=$ M.O. instrumento

Médiuns tecnotipicos, objetivos, que podem ser cartografados, com seus desempenhos mensuráveis (velocidade, superfície, volume, potência, custo, etc)

Mundo dos objetos
Agentes de circulação

1.Meio portador

(cultura romana, helenística, oeste-euro péia, norte-americana, etc...)

2.Corpo condutor,organismo de inserção ou pertença

(estabelecimento, empresa,instituiçãomuseu, editor, escola, emissora)

3.Código indutor (modos de configuração intema da mensagem)

$=0 . M$. gesto

Médiuns etno-históricos, relativos a uma engenharia subjetiva, com frequiência reflexo, imperceptivele coextensivo aos agentes

Mundo da vida 
Se aplico essa decupagem ao programa de televisão que vi ontem à noite, na minha aldeia, obtenho o seguinte. Suporte: tela-tubo catódico. V eículo: imagem-som eletrônico, direto ou em videoteipe. Rede: via hertiana terrestre (TDF, filial de FranceTélécom). M eio portador: o mundo francófono. Corpo condutor: estabelecimento industrial e comercial, público (emissoras de televisão France 2 ou 3) ou privado (TF1 ou Canal Plus). Código indutor: a mentalidade da casa, materializada na programação, de terminando roupagem, formato e gênero (talk-show, direto, variedade, bancada, etc...).

Três observações sobre esses cortes anatômicos:

1. As duas colunas designam realidades materiais objetivas, entremeadas de fato, mas que não são da mesma ordem. $O$ prédio escolar iria numa coluna; a instituição escolar em outra. Mas os dois estão mutuamente implicados. Dito isso, o segmento M.O. é da ordem do instrumento, do artefato, do conjunto de elementos inertes, manipuláveis e eventualmente desconectáveis. O segmento O.M. estaria antes mais próximo da ordem dos organismos, totalidades englobantes e vivas relativamente autônomas. Pensamos e comunicamos com M.O., mas em O.M. (um monge anacoreta do Monte Athos, sem meios de comunicação à disposição, continuará a rezar na sua língua, através da sua ordem e da sua igreja, nas formas litúrgicas da narrativa cristã).

Vê-se, com isso, que um dispositivo técnico de universalização espacial das mensagens, como o W orld W ide W eb, não invalida a hipoteca original das totalidades históricas à qual continuam atrelados, queiram ou não, os usuários da rede, começando pela língua utilizada que, por ser "natural", remete paradoxalmente a um território particular, a um determinado Estado, a uma comunidade instituída no tempo. "Uma língua é um dialeto com seus cânones." O inglês americano tem-nos mais do que o hindi. Comunicar em "america- no" (em francês ou em espanhol) não significa apenas utilizar um código, mas sim ipso facto propagar uma memória e adotar um programa; trata-se da atualização de uma relação político-econômica de forças pela qual se colabora, por pouco que seja e a despeito do que se tenha, à reprodução de uma totalidade necessária, histórica e institucionalmente dominante - a fortiori em detrimento das que dominou para impor-se como "natural".

2. Separados para fins de análise, esses segmentos formam um único conjunto, historicamente articulado. A invenção da escrita produziu texto (M.O.1); um novo sistema de reprodução de textos, a imprensa (M.O.2) produzirá em grandes quantidades objetos livros (M.O.3), inseparáveis de um meio técnico e humano de produção e de difusão de textos (o ateliê + a livraria); meio que suscita, por sua vez, a expansão e a oficialização das línguas nacionais (O.M.1), das diversas instituições da República das Letras - academias, bibliotecas reais, periódicos eruditos, sal as de leitura, etc. (O.M.2) - portadoras de matrizes discursivas e de formas precisas de sociabilidade (a noção e os direitos do autor, a forma epistolar, o discurso de acol hida, o salão, a "comunicação", etc...).

Dentro de cada bloco circulatório, o complexo causal não tem nunca sentido único nem está definitivamente repartido. Entretanto se a soma individual das operações simbólicas, M.O., opera sob as condições de O.M., não impede de supor que as revoluções técnicas, de M.O., determinam, a menor ou maior termo, as evoluções institucionais e mentais de O.M. Deixado de lado o determinismo, salientemos o seguinte: todos os patamares aqui abrigam forças produtivas, operantes e transformadoras, com efeitos cognitivos, imaginários, sociais e políticos próprios. Nenhum pode ser considerado inerte e neutro, tampouco o médium chamado de passivo.

3. Simplificando para esclarecer: o estudo dos fatos de comunicação, como o 
transporte de informações no espaço, pode, no limite, restringir-se aos diferentes patamares da M.O., enquanto o estudo dos fatos de transmissão, transporte no tempo, deve abranger as duas colunas, reinserindo as conexões estabelecidas ponto a ponto ou de um lugar a outro nas fileiras colegiais da longa duração transformadora. Experimente-se contar como Jesus de Nazaré se tornou "Cristo", e a figura ideal de "Jesus Cristo", cristianismo organizado e organizador, somente com ajuda dos "meios de comunicação" ou, na acepção comum, dos mídia. $^{2}$

Fase III - o meio. Se o médium, convertido em categoria integral de pensamento, tenta romper com a subestimação da ferramenta vista como instrumento, o inessencial meio das concepções humanistas, ele não poderia bastar-se a si mesmo. Pois se as relações entre os homens são mediatizadas pela interface técnica (resultado da ação do homem sobre a matéria), a própria matéria tem uma história, a dos meios técnicos que se sucederam no Planeta desde o primeiro sílex talhado. O século XIX, com Lamarck e Darwin, importou o termo e a noção de meio da mecânica para a biologia, iluminando repentinamente o mundo vivo. Para a elucidação dos meios culturais patamar superior de complexidade - não se pode esperar menos fecundidade. E numerosas são as vias de acesso à idéia de ecologia cultural.

Resumamos telegraficamente a contribuição da função meio:

1 - Ela impede a fetichização da região "mídia", tomando a parte pelo todo e o efeito pela causa. Assim como o homem, enquanto ser vivo, não escapa à lei geral dos seres vivos, as aparelhagens técnicas, batizadas de mídia, não fogem às leis tendenciais que dirigem à evolução da tecnosfera, tais como foram apontadas por Leroi-Gourhan e Simondon: crescente integração das funções, convergência das normas, miniaturização, rendimento maximal (obter o melhor resultado com o menor esforço possível), etc... Trata-se de um ramo entre outros dessa cadeia milenar de modo que, tanto quanto não possui em si mesmo as suas leis de geração, uma filosofia da comunicação não pode viver da sua própria substância. Exceto se efeito e estrutura forem confundidos.

2- Prevendo a miragem amnésica de uma modernidade auto-suficiente, merguIhada no inusitado, no sem precedente e na estupefação, a noção de meio reinsere prudentemente as atuais técnicas de transmissão/ comunicação na longa história das relações da espécie com a natureza. A dinâmica das transformações que opera em nosso meio ambiente material remete passo a passo ao paleolítico e esse prolongamento da história, sendo que análise em perspectiva é fonte de inteligibilidade. O midiólogo sofre espontaneamente de hipermetropia: melhor longe do que perto. Ele deve também treinar para lançar um olhar palenteológico sobre o seu meio mais próximo, observando de preferência o que os seus contemporâneos têm nos dedos do que nos lábios.

Préhistoriadores e arqueólogos figuram, nesse sentido, como midiólogos com mais sorte do que nós, pois só estando comprometidos com os testemunhos materiais do passado, não lhes cabe escolher. Devem reconstituir os universos simbólicos ultrapassados através dos materiais, objetos e instrumentos. Podem, através da "cultura material", atingir o osso da evolução social (o sílex, o ferro, o bronze...), sem ornamentos nem ilusões complacentes. Dito à nossa maneira: "A evolução humana é legível nos objetos, não nas ações". Se, por construção mental, podem ser vistos dois sapiens sapiens torturando um terceiro, jogando bola ou rezando, nenhuma dessas ações permitirá afirmar em que século ou milênio viveram tais homens. Em contrapartida, se eles têm nas mãos um chopper, uma machadinha ou uma serra elétrica, será possível imediatamente situá-los numa escala temporal. Datação aproximativa que não terá valor de julgamento, mas 
fornecerá um esclarecimento genealógico útil às maquinarias do momento.

Útil em quê? No que se refere às variações dos diferentes meios técnicos permitindo raciocinar a partir das similaridades e das diferenças, isolando, por observação, variações concomitantes (ou não), correlações funcionais existentes entre tal traço cultural e tal reviravolta técnica. A exemplo das ciências da observação (sem, contudo, ter pretensão ao mesmo estatuto), a midiologia é essencialmente comparativa; e só pode sêlo evoluindo livremente na diacronia maquinal, transportando idealmente um comportamento, um procedimento, um gesto artístico ou uma instituição social de um meio técnico antigo a um meio técnico novo para descobrir o que mudou e o que permaneceu.

3 - O meio descentra, pluraliza e relativiza. Substitui a entidade pela relação. N oção deliberadamente total itária, ajuda a desmontar o individualismo pretensioso do sujeito constituinte. Incita a pensar sobre "população", "nicho", "ecossistema”, no lugar das nossas caras ilusões de autonomia. As nossas idéias mais originais operam ainda por faixas, esferas de influência, situações interpostas; o sujeito comuni-cante (ritual "emissor") é com mais freqüência um coletivo delegado ou uma maquinaria incorporada. $\mathrm{O}$ dentro e o fora, mais o meio anônimo, externo-interno, esconde-se atrás da realidade sensível que faz existir (o englobante é sempre menos acessível que o englobado, e o museu parece-nos menos interessante do que o objeto que expõe e constitui assim em obra de arte).

4 - O meio explique. $O$ estribo, na China, não "produziu" a cavalaria; nem a imprensa, na Coréia, uma Reforma. Sem querer transportar cegamente o modelo darwiniano da luta pela vida, a noção de midiasfera (megameio de transmissão e de transporte) é um dos fatores que permite compreender a sobrevivência ou o desaparecimento de uma formação cultural, caso nos lembremos da definição da cultura dada por um biólogo, "resposta adaptativa ao meio" (Jacques Ruffié), ou ainda por um etnólogo, "a resposta dos homens às pressões dos meios onde vivem...". Nesse sentido, seria preciso levar a sério, para radicalizá-la nessa espécie particular de macrossistema técnico chamado "midiasfera", a seguinte observação banal: "Eis um tipo de intervenção, de discurso, de formato, de espírito, que não nunca passará na televisão...".

Cada um sabe que uma idéia justa ou uma invenção das mais úteis pode ser rejeitada por um meio adverso, despreparado para acolhêla. Não existiria a cada época uma seleção média das proposições de objetos e de idéias ao mesmo tempo conformes e filtradas pelo meio de transmissão, assim como há na natureza uma seleção pelo meio natural das espécies pertinentes ou performantes?

A midiologia (e nisso também ela se afasta da ortodoxia "infocom") gostaria de articular sistemas de comunicação e meios de locomoção. $O$ instrumental de uma sociedade constitui, de certa maneira, o esqueleto dos corpos simbólicos (de sua mentalidade, imaginário, crenças, de sua relação concreta com o espaço e com o tempo abstrato) e determina um espaço-tempo prático, medido pelas suas capacidades (tecnicamente determinadas) de memorização e de deslocamento. O espaço aumenta e diminui em função da velocidade, e o tempo dilata-se ou contrai-se em função das mnemotécnicas disponíveis. O transmissor divide-se com dificuldade entre o espaço e o tempo (durante muito tempo confundidos, enquanto a velocidade de circulação das mensagens correspondeu mais ou menos à dos homens).

Depois da arrancada dos anos 1840, no Ocidente, é inevitável observar que telecom e transportes "avançam" num mesmo passo a cada geração tecnológica: o telégrafo el étrico fez par com as ferrovias; o telefone, com o automóvel; a radiofonia, com a aviação; a televisão intercontinental, com os lançamentos espaciais.

Simbólico não é, por etimologia, tudo o 
que reúne e liga? A quilo que nos faz partiIhar um mesmo tempo e um mesmo espaço? Estar junto, seja qual for o tamanho do agrupamento (clã, tribo, nação, federação) é fazer território e transformar. A maneira de fazer território depende dos meios de locomoção; a maneira de transformar, dos meios de consignação. A comunicação de mensagens lingüísticos é apenas uma parte da articulação simbólica - e não talvez não a mais funcional. Sem dúvida, a capacidade de modificar a economia do espaço e do tempo não é dada a qualquer ferramenta, máquina ou instrumento. Todo objeto trabalhado (M.O.) faz sentido e signo: a vestimenta, a cama, o instrumento de cozinha. "Estude-se um objeto, dizia Haudricourt, e sociedade virá junto." Um código social e uma personalidade étnica podem abrigar-se numa cafeteira, num arado, num cabo de faca. Qualquer objeto, seja ele utilitário, pode ser um semáforo; não é qualquer objeto que permite vencer a ausência ou encurtar as distâncias, domesticar a extensão e a duração. O relógio o faz, e o papel, indiretamente, como agente formidável da conservação e da circulação no espaço; não a banheira ou o garfo.

A máquina de lavar, a tábua de cortar carne e a casa não entram nessa categoria; a máquina de escrever, o cálamo e o monumento, sim. Estes artefatos são explicitamente destinados a registrar e perpetuar uma informação. Assim, prevalecerá o interesse prioritário sobre tudo o que possa aumentar a velocidade do bípede. A própria vida é conquista de mobilidade, e a técnica, "prolongação da vida por outros meios" (Leroi-Gourhan). Assim como a escrita foi uma extensão do cérebro, a roda foi uma extensão da perna; e o duas rodas, uma prolongação da vida através do pedal. Primeiro engenho de locomoção individual, a bicicleta redimensionou o próximo e longínquo, pôs em relação os isolados, ao ampliar horizonte individual, e reduziu os territórios.

O alfabeto vocálico, máquina coletiva de decompor os sons, redistribui o atual e o antigo, impulsionou as significações, perturbou os regimes de autoridade. Uma escrita é uma cronotécnica; uma bicicleta, uma espaciotécnica. Esses dois suplementos de vida, não programados geneticamente, não funcionam apenas como indicadores, mas também como embreagens de um novo mundo cultural, a historicidade, a mobilidade para todos. Não forcemos em demasia o barroco transversal a ponto de colocar no mesmo plano uma tecnologia intelectual axial e um acessório mecânico importante; eis o que poderia fazer uma primeira triagem entre as pequenas coisas banais que nós interessam e as outras.

Nada do que é material nos é estranho? Não. Muitos utensílios nos são indiferentes, ainda que possam ser capitais e apaixonantes para um etnólogo ou um historiador: o mobiliário, as bijuterias, os bidês, as lâmpadas. Só nos interessa a tulha dos trastes e objetos suscetíveis de modificar as relações sensíveis de homem a homem ao alterar-Ihes o tempo e o espaço vividos - traçados, cercados, representados, cartografados e transportáveis. Ou seja, o meio, indissoluvelmente físico e simbólico, espacial e mental: a midiasfera.

Fase IV e última - a mediação. O sufixo de ação vem por último para dinamizar as etapas anteriores. Mobilização do inerte e retroação lógica. A mediação recua para entrar na mensagem, a qual não existe independentemente dos seus médiuns e meios de transmissão. Esta não é o ponto de partida, mas o resultado do seu próprio processo de transmissão (Jesus descende do Cristo, e não o contrário). Passar do pronto e acabado ao em construção, e do transmissor ao transformador, não é tão fácil quando se possa imaginar, até porque o médium é, em geral, e os mídia em particular, uma mediação renegada, auto-rasurada (uma boa transmissão é uma transmissão que se apaga e quanto mais técnica for, mais saberá se fazer passar por natural).

Os mídia aperta-botão - fascinante magia, casa surpreendente, dopante inde- 
tectável - caracterizam-se por irradiar pelo corpo a sensação mesma de imediaticidade (ou a impressão de uma equivalência fatos/ informação, como se o apareIho de informação não coletasse, não reenquadrasse, não amplificasse e, enfim, não fabricasse o fato).

Modo operatório, a mediação é fundamentalmente um estatuto zoológico - o selo próprio ao animal humano, a causa do seu incessante devir. O sapiens sapiens é um em construção, um recorrente dentro/ fora, um sistema constantemente relançado de socorro mútuo entre a mão e a face, o gesto e a palavra - título do livro recapitulativo (e para mim fundador) de André Leroi-Gourhan. $\mathrm{Na}$ esteira de Mauss (que mostrara o quanto nossos comportamentos mais naturais são mediatizados por uma aprendizagem técnica), mas com maior precisão documental e distanciamento, o préhistoriador estabeleceu que a língua e o instrumento são "a expressão da mesma propriedade do homem" (1964, p. 1963).

Mais do que prótese, acréscimo ou complemento, Leroi-Gourhan nos faz descobrir no objeto fabricado um elemento constitutivo do sujeito fabricante, a história dos seus instrumentos tornando-se a própria história da espécie (ou mesmo, na minha humilde opinião, nossa única história verdadeira, não repetitiva e não programada, como o é, sob tantos aspectos, a história dita política e social), o único domínio onde "isso se movimenta mesmo". A técnica inventou o homem; a tecnogênese é a face externa da antropôgenese; o humano constrói-se através do não-humano. Ao filósofo, teólogo envergonhado, que não se cansa de denunciar a "desumanização" (reificação, alienação, inautenticidade, técnica como metáfora da queda e do pecado original), o antropólogo responde: não, hominização.

A mediação pela exteriorização não é o mau momento da interioridade, mas o momento forte da humanitude. $\mathrm{O}$ objeto força o sujeito a superar-se. Multiplica-o, intensifica-o, prolonga-o. A biblioteca ultra- passa as capacidades de nossa memória; o livro é mais profundo do que o seu autor; "o instrumento vale mais do que nossa mão", "os aparelhos estão adiante dos homens", como o repete, frente e contra os nossos idealismos-reflexos, François Dagognet, nosso grande perturbador transportador. Por isso, os que sabem analisar as máquinas do dia, exploram o amanhã dos homens.

Advinha-se que a abordagem midiológica poderia conduzir um dia para além de valorização renovada dos instrumentos concretos do pensamento (as tecnologias intelectuais) e dos vetores de transporte (as engenharias espaciais). Tarefa bastante adiantada por diversos pesquisadores (Goody, Latour, Havelock, etc...). Ela poderia desembocar numa nova maneira de filosofar, de descrever o mundo e de contar histórias. A consideração do efeito-retorno não data tampouco de hoje. Etnólogos e sociólogos ensinaram-nos o que o homem faz aos seus instrumentos (a marca social dos artefatos). Tecnólogos e epistemólogos ensinaram-nos o que os instrumentos fazem ao homem (bem, mais do que tudo). A diagonal midiológica cruza os registros "técnica" e "cultura", instrumental e societal, que não são, como se sabe, continentes separados nem entidades em si (exceto nas gigantomaquias apocalípticas "o Homem contra as Máquina").

Essa atitude faz emergir uma lógica ternária e não binária, distante do nosso dualismo hereditário. Força o doloroso afastamento do solo grego e das oposições fósseis que ainda nos teleguiam: original/ cópia, potência/ ato, interno/ externo, substrato/ fenômeno, espiritual/material. Sem dúvida, são preferidos, na atualidade, outros duos mais "tecnos": real/ virtual, suporte/ código, vetor/ mensagem, etc. Legado, o jugo não é este, em segredo, de uma teologia preguiçosa e espontânea; depois, um processo; um criador, depois as criaturas; uma essência; depois, os seus fenômenos; um Fim ideal; depois, os meios de subordiná-los? 
A reviravolta midiológica não se faz naturalmente. Não, não é fácil admitir, e ainda menos fazer admitir, que a origem é aquilo que se põe no fim; que o meio exterior está no interior da mensagem; que a periferia está no centro do núcleo; que o transporte transforma; que o material de inscrição dita a forma da escrita; e que, em geral, as nossas finalidades se ajustam aos nossos recursos. Não existe, perdão, Péguy, de um lado a (boa) mística e de outro a (má) política. O espírito vem através do corpo, é "corpo". A mística é a recompensa de um realismo bem conduzido, e o pragmatismo agonizaria na ausência de uma mística qualquer. Nada de entidades em face, de correlações em funcionamento.

Aquilo que se pode traduzir, em termos de programa de pesquisa, como um “objeto de estudo, não é um objeto, nem uma região do real (os mídia), mas as relações entre objetos, ou regiões". Entre uma idealidade e uma materialidade; um sentimento e uma máquina; uma disposição e um dispositivo. $\mathrm{Na}$ fórmula hugolina, isto matará aquilo, não é o verbo que conta (pode-se discutir isso), mas o quadro de dupla entrada, isto e aquilo, Gutenberg e a arquitetura, o tipo móvel de chumbo e a autoridade do papa. O estudo da bicicleta em si nada tem de midiológico, salvo quando se examina a relação existente entre a invenção da bicicleta e o feminismo, o cinetismo em arte, o individualismo democrático, etc. O estudo da idéia de nação tampouco, salvo quando se considera tudo o que ela deve às rodovias, ferrovias, correios, telégrafos elétricos e o que sobrevem com uma segunda geração de infra-estruturas transmissoras.

Um estudo do desejo de imortalidade seria bem-vindo em si, mas só se tornaria midiológico com a decisão de mostrar como esse sentimento moral se transformou, em contato e sob o efeito da pintura, do cinema, da televisão e da evolução das técnicas figurativas em geral. Assim, o que os fenomenólogos reclamavam de uma "variação eidética" (modificar idealmente as propriedades de um objeto empírico para descobrir-Ihe intuitivamente a essência), o midiólogo exige das variações tecnológicas de uma faculdade, de um comportamento, de uma instituição ou de um traço natural.

Elucidação cuja fecundidade aumentará com o risco epistemológico, conforme o grau de abertura do enquadramento. Permanecer num primeiro grau de análise, a interação intra-sistema, limita os riscos. Por exemplo, para o livro, o modo impresso de reprodução (técnica) e a organização interna dos textos (cultura); para a imagem fixa, a digitalização e a foto artística (o que o computador faz aos Cartier-Bresson); ou ainda, para o cinema, como o videocassete perturbou o cinéfilo. ${ }^{3}$ Passar ao segundo grau, interação inter-sistemas, aumentará o prazer. Por exemplo, o que o aparecimento da fotografia modificou na arte de pintar e na arte em geral (Walter Benjamin tendo neste ponto dado o exemplo); o que a eletricidade mudou na arquitetura (elevadores e arranha-céu); ou o direto televisionado em relação ao Tour de France, produto direito do jornal impresso.

Pode-se assim, sob o risco do inverificável, à primeira vista, atingir o nirvana da iluminação, ao "conhecimento do terceiro gênero", se são abordadas as interações trans-sistêmicas. Por exemplo, as relações de dependência unindo a tipografia ao chumbo e à ideologia socialista (Régis Debray, Cours de médiologie général), o cinema e a construção nacionalitária (Jean-Michel Frodon, La projection nationale) ou, ainda, os modos de representação visual e as disposições pessoais ao heroísmo (Hélène Puiseux, Les figures de la guerre). Uma mesma pesquisa, claro, pode abranger graus sucessivos, desde que estejam documentados, ligando como pertinentes os isto e aquilo mais distantes, em aparência - um mesmo fenômeno podendo assim se revelar passível dos três níveis de correlação indicados.

Confessemos: a razão midiológica não é a última palavra da história. Para o sapateiro, é o sapato que faz os homens anda- 
rem; para o erudito ou epistemólogo, a aquisição de conhecimentos está acima de tudo, sendo que do saber bem dividido sairão a democracia, o amor e a fraternidade humana; para o economista, tudo aqui embaixo é trabalho e valor; para o psicanalista, a libido leva ao baile; e o jurista faz girar o universo sobre o código civil. Idiotismos profissionais.... Um artesão midiólogo, por seu lado, não esquece que há mais coisas na terra e no céu do que em toda a midiologia passada, presente e futura. Não vê meio-dia no seu médium. Diz-se simplesmente: eis, talvez, senão uma fonte particular de conhecimento a esperar, ao menos um modo original de conhecimentos a explorar .

\section{Notas}

10 midiólogo ambidestro vêse assim dividido entre duas cadeiras, isto é, às voltas com duas frentes de batalha. Oporá em vão a materialidade técnica do instrumento aos defensores do "tudo é político" e as determinações políticas da instrumentação aos partidários do "tudo é técnica". À direita, servirá de ranzinza estraga-prazer às utopias (otimistas, simpáticas, fraternais) da tecnodemocracia, conectadas, atualmente, com a revolução digital (a exemplo, para ficar no melhor do melhor, o "universal sem totalidade" de nosso amigo Pierre Lévy). À esquerda, ombreará com os "cães de guarda" nos panoramas surpreendentes (negros, desconstrutores e desmitificadores) das manipulações de classe, mecânicas de submissão das massas e sistemas de dominação simbólica em atividade (ilustrada hoje por meu amigo Pierre Bourdieu e a sua escola).

2 Cada um poderá, diante disso, divertir-se em validar ou contestar essa grade de leitura preenchendo os espaços pontilhados conforme os próprios interesses. Midiologia do fenômeno cristão ao longo dos dois primeiros séculos? Leia-se Sachot. Coluna da esquerda para os vetores e suportes materiais: escrita oralizada, visual inexistente; microcomunidades de memória, com pregadoresorganizadores itinerantes ao longo das rotas marítimas e terrestres do Imperium. Papiro + homilia (à espera do irresistível codex). Coluna da direita para os vetores institucionais: 0 aramaico, seguido da dicção da mensa- gem em língua grega, depois da destruição do Estado de Israel (fenômeno político de conseqüências teológicas decisivas); a seita neojudaica, posteriormente a escola de pensamento, a scholé helênica; 0 modelo da homilia sinagogal substituído pela do discurso da verdade à gre ga. Todos esses elementos dependem de um macromeio de transmissão claramente identificável em termos históricos: a logosfera.

Midiologia de uma das belas-artes, a pintura, no instante "t"? M.0.1 = materiais utilizados (pigmentos, óleo, tela, moldura, etc...). M.0.2 = disposição interna da profissão (ateliê, academia, escola, assistentes, etc...). M.0.3 = tipos de objetos manufaturados (móveis, imóveis, quadros, afrescos, gravuras, etc...). 0.M.1 = códigos figurativos (perspectiva linear, "maneiras" ou convenções sociais). $0 . M .2$ = organização institucional dos fabricantes e agentes de circulação do gosto (museus, galerias, colecionadores, críticos, leiloeiros, etc...). 0.M.3 = rituais do catálogo, vernissages, leilões, celebração, reuniões em escolas ou movimentos, valorizações do artista, etc. É, claro, artificialmente que se distingue, no papel, 0 que deve restar, de fato, confuso para poder gerar, com toda inocência e espontaneidade, tanto junto aos estetas quanto aos artistas, 0 efeito-pintura.

Em arte, os homens entrelaçam-se de tal maneiras com as coisas que não se sabe mais, ou sobretudo não se deve saber, o que é relativo à criação ou à recepção, e se 0 objeto artístico faz o sujeito do gosto ou o inverso. Nossa história estetizante da pintura universal atém-se à sucessão interna de criações singulares: compõe, com Elie Faure, Malraux e René Huygue (para ficar nos compatriotas), a grande galeria dos demiurgos. A história social da arte, com Haskell, Baxandall e Alpers, focaliza os me diadores de arte, os que encomendam, os colecionadores, os marchands, ou seja, o meio "externo". M.0. contra 0.M. 0 midiólogo suspira no ir e vir M.0.-0.M., através de incessantes e minúsculos vaivéns.

3 Ver, sobre esse aspecto, a admirável análise, de um rigor propriamente midiológico, de Dominique Païni, "Faire violence", in Cahiers du cinéma, maio 1998. 